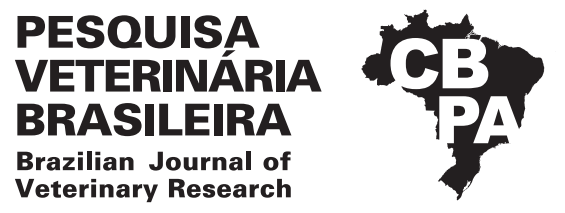

Pesq. Vet. Bras. 39(3):175-178, March 2019 DOI: $10.1590 / 1678-5150-P V B-6185$

Original Article

ISSN 0100-736X (Print) Livestock Diseases

ISSN 1678-5150 (Online)

\title{
Molecular detection of albinism gene in Brazilian buffalo herds (Bubalus bubalis) ${ }^{1}$
}

\author{
Pedro N. Bernardino², Aline F.A. Martins², José D. Barbosa ${ }^{3}$, Ana L. Schild ${ }^{4}$, \\ Maria Cecília F. Damé ${ }^{5}$, Alexandre S. Borges ${ }^{2}$ and José P. Oliveira-Filho ${ }^{2 *}$
}

\begin{abstract}
Bernardino P.N., Martins A.F.A., Barbosa J.D., Schild A.L., Damé M.C.F., Borges A.S. \& Oliveira-Filho J.P. 2019. Molecular detection of albinism gene in Brazilian buffalo herds (Bubalus bubalis). Pesquisa Veterinária Brasileira 39(3):175-178. Departamento de Clínica Veterinária, Faculdade de Medicina Veterinária e Zootecnia, Universidade Estadual Paulista, Rua Prof. Doutor Walter Mauricio Correa s/n, Cx. Postal 560, Botucatu, SP 18618-681, Brazil. E-mail: jose.oliveira-filho@unesp.br

Albinism is a genetic disease characterized by deficient melanin production making affected animals more susceptible to skin problems, negatively influencing production systems of the same. In buffalo, a nonsense mutation (c.1431G>A) in the tyrosinase gene was already described, which is responsible for the oculocutaneous albinism buffalo phenotype. However, prevalence studies have never been performed for this anomaly in Brazil. Therefore, the objective of this study was to investigate this mutation in buffalo herd in Brazil. Of the 315 buffalo tested with no albinism phenotype evident, 11 (3.5\%) were heterozygous for the mutation and none were mutated homozygous, showing the existence of the albinism gene in buffalo production herds and proving the importance of prevalence studies for hereditary diseases in order to prevent the dissemination of these same genes and their negative productivity consequences.
\end{abstract}

INDEX TERMS: Molecular detection, albinism gene, buffalo, herds, Bubalus bubalis, mutation, tyrosinase, prevalence, genetics.

RESUMO.- [Detecção molecular do gene do albinismo em
rebanhos de búfalos (Bubalus bubalis) do Brasil.] 0 Albinismo
é uma doença genética caracterizada pela deficiência na
produção de melanina, o que torna os animais afetados mais
susceptíveis a problemas cutâneos e influencia negativamente
a criação destes animais. A mutação nonsense (c.1431G>A)
no gene da tyrosinase já foi descrita como responsável pelo
albinismo oculocutâneo em búfalos, entretanto estudos
prévios sobre a prevalência dessa mutação ainda não foram

\footnotetext{
${ }^{1}$ Received on November 6, 2018.

Accepted for publication on November 22, 2018.

${ }^{2}$ Departamento de Clínica Veterinária, Faculdade de Medicina Veterinária e Zootecnia, Universidade Estadual Paulista (Unesp), Rua Prof. Doutor Walter Mauricio Correa s/n, Cx. Postal 560, Botucatu, SP 18618-681, Brazil. *Corresponding author: jose.oliveira-filho@unesp.br

${ }^{3}$ Instituto de Medicina Veterinária, Faculdade de Medicina Veterinária, Universidade Federal do Pará (UFPA), Campus de Castanhal, Rodovia BR-316 Km 61, Castanhal, PA 68741-740, Brazil.

${ }^{4}$ Laboratório Regional de Diagnóstico, Faculdade de Veterinária, Universidade Federal de Pelotas, Rua Gomes Carneiro 1, Centro, Pelotas, RS 96010-610, Brazil.

${ }^{5}$ Embrapa Clima Temperado, Campus Universitário s/n, Capão do Leão, RS 96010-971, Brazil.
}

realizados no Brasil. Portanto, o objetivo deste estudo foi avaliar a presença desta mutação em uma população de búfalos brasileiros. Foram genotipados 315 búfalos clinicamente normais, ou seja, sem o fenótipo albino evidente. Desses, $11(3,5 \%)$ eram heterozigotos para a mutação (N/TYR) e os demais eram homozigotos selvagens $(\mathrm{N} / \mathrm{N})$. Este resultado demonstra que o alelo mutado para o albinismo em búfalo está presente no rebanho brasileiro e aponta a importância de estudos de prevalência de enfermidades hereditárias com o objetivo de prevenir a disseminação desses alelos mutados, minimizando os prejuízos.

TERMOS DE INDEXAÇÃO: Deteç̧ão molecular, gene do albinismo, rebanhos, búfalos, Bubalus bubalis, mutação, tirosinase, prevalência, genética.

\section{INTRODUCTION}

Genetic Type 1 oculocutaneous albinism (OCA) is an autosomal recessive genetic anomaly in which the production of melanin is reduced or inexistent due to a point mutation that decodes the tyrosinase gene (TYR), enzyme that takes part on the melanin synthesis process (Oetting 2000). It was already described in 
multiple species: albino Wistar lab rats present a nucleotide shift in the TYR gene (Blaszczyk et al. 2005), in albino cats it is observed a deletion of a cytosine in the TYR gene producing a premature stop codon (Imes et al. 2006), bovines showed a insertion of a cytosine in the same gene also originating a premature stop codon (Schmutz et al. 2004), and yet, albino ferrets presented a deletion in exon 4 of the TYR gene (Blaszczyk et al. 2007). In buffalo, a nonsense mutation in the nucleotide 1431 ( $\mathrm{G}$ to $\mathrm{A}$ ) was pointed to produce an inactive TYR protein resulting in animals with photophobia and skin, hair, hooves, horns, iris and mucous membranes depigmentation, characteristic of OCA (Damé et al. 2012).

According to the Brazilian Association of Buffalo Farmers, the Brazilian buffalo herd was around 3.5 million animals in 2007. This population started in the late XIX century with only 200 animals, adding a few pure buffalo from India in 1962 and 8 from Italy in 1989 (Bernarde 2007). The large population growth based on few starters indicates high probabilities of consanguinity, which allows the propagation of mutated genes for hereditary diseases, as the TYR mutation for albinism.
Individuals without adequate pigmentation (Fig.1) are more susceptible to skin and eyes problems, such as sun burnt, retinal lesions and melanomas (Damé et al. 2015, Fuller \& Hay 2015). Those could affect negatively the buffalo production system, making the albinism an undesirable characteristic. No prevalence data concerning this disease in Brazil exists so far, only case reports (Damé et al. 2012) proving the presence of this mutation in the herds and making the selection for breeding based on genetic aspects more important in this specie. Therefore, the objective of this study was to investigate this mutation in buffalo herd in Brazil.

\section{MATERIALS AND METHODS}

Ethics statement. All procedures were approved by the Board of Ethics and Animal Experimentation of the institution (Protocol no. 54/2016 - CEUA).

Experimental samples. For the present molecular study, hair, blood or semen samples were collected from 315 Murrah buffalo from Southern (states of Rio Grande do Sul and Paraná), Northern

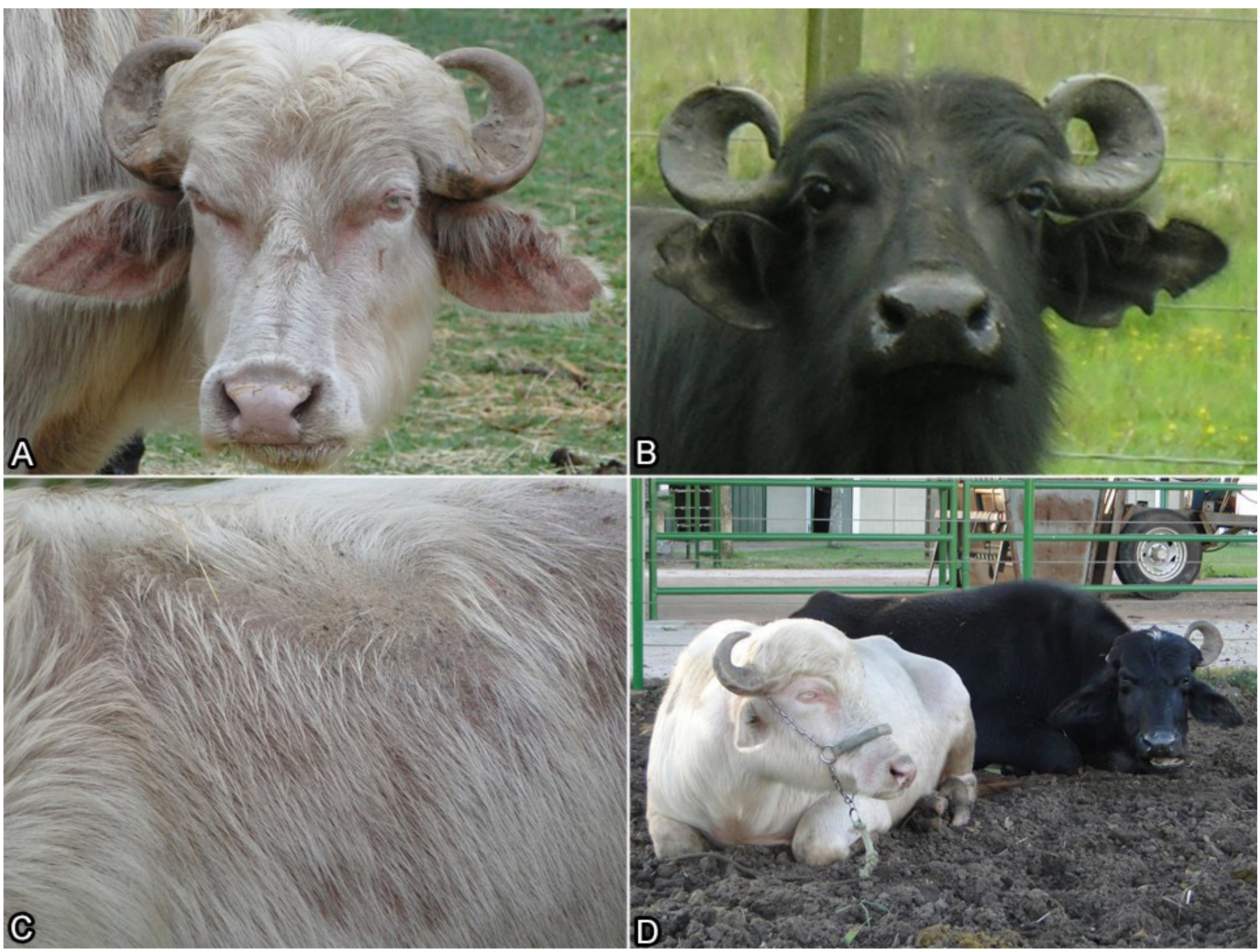

Fig.1 (A) Oculocutaneous albinism (OCA) Murrah buffalo, showing white skin and the stratum corneum of the horns; mucosa and periocular region (eyelashes, conjunctiva and iris) with absence of pigmentation. (B) Normal Murrah buffalo with black skin. (C) Depigmented skin and hairs of the dorsal region of an OCA buffalo. (D) An OCA albino bull and normal cow buffalo. 
(state of Pará) and South-Eastern (state of São Paulo) Brazilian properties, with no sex, age or breed predilection. Blood and semen samples were refrigerated until the extraction.

DNA purification and genotyping analysis. Genomic DNA was purified from hair root samples using an in-house method and from blood and semen samples using the GenElute ${ }^{\mathrm{TM}}$ Genomic Blood DNA Kit (Sigma-Aldrich ${ }^{\circledR}$ ) according to the manufacturer's instructions. The DNA obtained was used to genotype the mutation c.1431G $>A$ in the TYR gene. The PCR was performed using ASBTYR-F3 and ASBTYR-R3 primers previously described for OCA in buffalo (Dame et al. 2012). The PCR amplifications were performed in a total volume of $25 \mu \mathrm{l}$, which contained $0.3 \mu \mathrm{M}$ each forward and reverse primer, $2.5 \mu \mathrm{l}$ of template cDNA, $12.5 \mu \mathrm{l}$ of GoTaq ${ }^{\circledR}$ Green PCR Master Mix (Promega), and nuclease-free water q.s.p. In addition, a no-template control reaction was performed in duplicate to check for the possible presence of contamination in the preparations, besides that, a positive control (DNA from OCA buffalo) was used in order to ensure that the reaction worked well. The obtained PCR products were analyzed via 1.5\% agarose gel electrophoresis (Invitrogen ${ }^{\mathrm{TM}}$, Carlsbad, CA), stained with the Sybr ${ }^{\circledR}$ Safe DNA Gel Stain (Invitrogen ${ }^{\mathrm{TM}}$ ) and then purified using the QIAquick $^{\circledR}$ PCR Purification Kit (Qiagen ${ }^{\circledR}$ ).

Sequencing analysis. To sequence the DNA, $10 \mu \mathrm{L}$ of each PCR product, $5 \mu \mathrm{L}$ of the purified forward primer and the BigDye ${ }^{\circledR}$ Terminator Cycle Sequencing Kit were used (Life Technologies ${ }^{\mathrm{TM}} \mathrm{CA}$, USA). The sequences were determined using the ABI 3500 Genetic Analyzer (Life Technologies ${ }^{\mathrm{TM}}$ CA, USA). The obtained sequences and the electropherograms (Fig.2) were analyzed using Geneious ${ }^{\circledR}$ 10.0.9 (Biomatters Ltd, Auckland, New Zealand). The sequences were compared with the normal Bubalus bubalis TYR gene sequence using BLAST (Basic Local Alignment Search Tool, <http://blast.ncbi. nlm.nih.gov/Blast.cgi>). The genotypic frequency was estimated and the data were analyzed descriptively.

\section{RESULTS AND DISCUSSION}

None of the buffalo included in the study presented the phenotype for albinism, fitting the result of no mutated homozygous individual (0\%). Despite not having albino animals, 11 out of the 315 buffalo (3.5\%) were heterozygous for the TYR gene mutation as seen in the electropherogram (Fig.2), the other 304 (96.5\%) are non-mutated homozygous individuals (Table 1). The heterozygous animals were present in two of the properties that took part on this research: 6 out of 111 animals (5.4\%) from the state of Rio Grande do Sul and 5 out of $46(10.8 \%)$ from the state of Para. The other properties presented $100 \%$ of the sampled animals as non-mutated homozygous.

Knowing which animals have the mutation for the TYR gene, the farmers of each property can take this information in consideration during the selection of breeders, avoiding these anomalies in new animals. In addition, if buffalo are purchased from other properties, the genetic test can help to show if the incomes carry the mutation or not in order to select them as breeders as well.

Besides albinism, other buffalo diseases have been confirmed to be hereditary or have strong evidences of being carried through the genes like arthrogryposis, hereditary myotonia, and hydranencephaly (Damé et al. 2013). Precautions should be taken to avoid the propagation of those diseases and their adverse effect on buffalo production system (Damé et al. 2015). For this reason, prevalence studies on genetic disorders

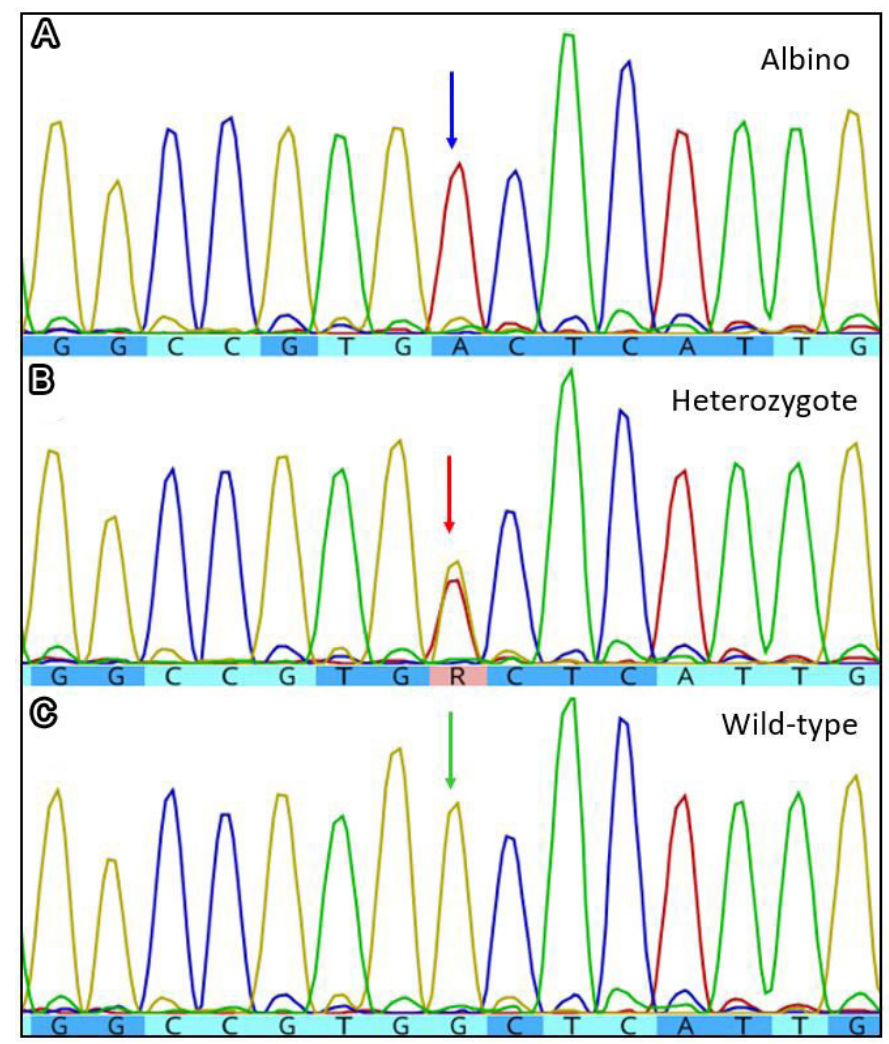

Fig.2 (A) Partial electropherogram obtained from albino (positive control), (B) heterozygote and (C) wild-type buffalo. It is possible to observe a double peak (R, G/A) in the heterozygous (red arrow), and a single peak in albino (A nucleotide, blue arrow) and in wild-type buffalo (G nucleotide, green arrow). Image obtained in the Geneious ${ }^{\circledR}$ 10.0.9 software (Biomatters Ltd, Auckland, New Zealand).

Table 1. Prevalence of heterozygous (N/TYR) and wild-type $(\mathrm{N} / \mathrm{N})$ Murrah buffalo for the mutation c.1431G $>\mathrm{A}$ in the TYR gene responsible for albino buffaloes

\begin{tabular}{lccc}
\hline & $\begin{array}{c}\text { Heterozygotes } \\
(\mathrm{N} / \mathrm{TYR})\end{array}$ & $\begin{array}{c}\text { Wild types } \\
(\mathrm{N} / \mathrm{N})\end{array}$ & Total sampling \\
\hline $\begin{array}{l}\text { Frequency } \\
\begin{array}{l}\text { Number of } \\
\text { animals }\end{array}\end{array}$ & $3.5 \%$ & $96.5 \%$ & $100 \%$ \\
& 11 & 304 & 315
\end{tabular}

aiming in the identification of heterozygous animals give information for future references on which animals should be used or not for reproduction.

\section{CONCLUSIONS}

The study shows the existence of a gene mutation without phenotype manifestation for one of many genetic diseases among buffalo of more than one herd in different properties of the same country.

This proves the importance of molecular prevalence studies both for the production system that should be careful not to propagate the mutation and for the scientific community that can understand more about the disease's epidemiology. 
Acknowledgments.- This study was carried out at the Universidade Estadual Paulista (Unesp). This study was supported by a grant from the CAPES (Coordenação de Aperfeiçoamento de Pessoal de Nível Superior, AUX-PEPREMIO, 432/2014) and by a grant from the FAPESP (Fundação de Amparo à Pesquisa do Estado de São Paulo) 2015/23569-4 (scholarship to PNB).

Conflict of interest statement. - The authors declare that there are no conflicts of interest.

\section{REFERENCES}

Bernarde 0. 2007. Bubalinocultura no Brasil: situação e importância econômica. Revta Bras. Reprod. Anim. 31:293-298.

Blaszczyk W.M., Arning L., Hoffmann K.P. \& Epplen J.T. 2005. A tyrosinase missense mutation causes albinism in the Wistar rat. Pigment Cell Res. 18(2):144-145. <http://dx.doi.org/10.1111/j.1600-0749.2005.00227. $\mathrm{x}><$ PMid:15760344>

Blaszczyk W.M., Distler C., Dekomien G., Arning L., Hoffmann K.P. \& Epplen J.T. 2007. Identification of tyrosinase (TYR) exon 4 deletion in albino ferrets (Mustela putorius furo). Anim. Genet. 38(4):421-423. <http://dx.doi. org/10.1111/j.1365-2052.2007.01619.x><PMid:17655555>

Damé M.C.F., Riet-Correa F. \& Schild A.L. 2013. Doenças hereditárias e defeitos congênitos diagnosticados em búfalos (Bubalus bubalis) no
Brasil. Pesq. Vet. Bras. 33(7):831-839. <http://dx.doi.org/10.1590/S0100736X2013000700001>

Damé M.C.F., Marcolongo-Pereira C., Fiss L., Adrién M.L. \& Schild A.L. 2015. Malignant melanoma in albino water buffalo (Bubalus bubalis). Semina, Ciênc. Agrárias 36:3239-3244.

Damé M.C.F., Xavier G.M., Oliveira-Filho J.P., Borges A.S., Oliveira H.N., RietCorrea F. \& Schild A.M. 2012. A nonsense mutation in the tyrosinase gene causes albinism in water buffalo. BMC Genet. 13(1):62-68. <http://dx.doi. org/10.1186/1471-2156-13-62><PMid:22817390>

Fuller C. \& Hay R. 2015. Albinism: a cause for concern. Community Dermatol. J. 11:1-12.

Imes D.L., Geary L.A., Grahn R.A. \& Lyons L.A. 2006. Albinism in the domestic cat (Felis catus) is associated with tyrosinase (TYR) mutation. Anim. Genet. 37(2):175-178. <http://dx.doi.org/10.1111/j.1365-2052.2005.01409.x> $<$ PMid:16573534>

Oetting W.S. 2000. The tyrosinase gene and oculocutaneous albinism type I (OCA1): a model for understanding the molecular biology of melanin formation. Pigment Cell Res. 13(5):320-325. <http://dx.doi. org/10.1034/j.1600-0749.2000.130503.x><PMid:11041207>

Schmutz S.M., Berryere T.G., Ciobanu D.C., Mileham A.J., Schmidtz B.H. \& Fredholm M. 2004. A form of albinism in cattle is caused by a tyrosinase frameshift mutation. Mammalian Genome 15(1):62-67. <http://dx.doi. org/10.1007/s00335-002-2249-5><PMid:14727143> 